\title{
Networked capital: indirect investment and BIT formation
}

\author{
Andrey Tomashevskiy (D) \\ Department of Political Science, Rutgers The State University of New Jersey, New Brunswick. NJ 08901-8554, USA \\ Corresponding Author: Andrey Tomashevskiy, Rutgers University; Email: a.tomashevskiy@rutgers.edu
}

\begin{abstract}
Why do states participate in bilateral investment treaties (BITs)? In this article, I examine the role of indirect investment on BIT formation. Indirect investment flows are an important aspect of the global investment regime that are underexamined by research focused on direct flows only. Indirect flows play an important role in affecting incentives for BIT participation because firms channel investment through intermediary destinations to take advantage of existing BITs. I argue that governments are more likely to participate in BITs when states expect to access groups of capital exporting states through second order links. When selecting BIT partners, states evaluate expected indirect foreign direct investment (FDI) flows by considering characteristics of a potential partner's second order FDI partners. States are thus more likely to participate in BITs when expectations for indirect flows are high. I use a variety of analyses to demonstrate evidence in favor of my hypotheses. I find evidence that indirect flows affect the likelihood of BIT formation and increase dyadic FDI flows. This research provides a novel explanation for BIT formation and contributes to research on indirect capital flows, treaty shopping and BIT formation.
\end{abstract}

Keywords: bilateral investment treaties; social network analysis; indirect investment; treaty shopping

\section{Introduction}

Bilateral investment treaties (BITs) are a prominent part of the international investment regime, with nearly every country a member of at least one BIT. ${ }^{1}$ Given that BITs are a widely used policy instrument, it is important to understand why states sign BITs. A common explanation argues that states sign BITs to increase flows of foreign direct investment (FDI). ${ }^{2}$ BITs are designed to govern the process of foreign investment; in signing BITs, states surrender some portion of their sovereignty and agree to be bound by the terms of the BIT in treating FDI at home. When investor host states sign BITs, they do so to credibly commit to protect investor property rights and to receive greater inflows of FDI. The FDI promotion incentive is particularly important for developing states facing a time inconsistency problem when dealing with foreign investors. Because FDI is immobile once the investment decision is made, the host state is free to renege on previous agreements and either engage in direct expropriation or change the terms of the investment to collect larger rents. When investment risk is very large and risks outweighs potential returns, investors may choose not to invest altogether or to invest in some other location.

The use of BITs as a credible commitment device has contributed to the spread of BITs. States hoping to attract capital feel competitive pressures to sign BITs: States that do not participate in BITs are at a competitive disadvantage in attracting FDI capital compared to states that do participate in BITs . ${ }^{3}$ However, existing explanations of BITs do not account for the role of indirect FDI flows. The formation of BITs creates incentives and opportunities for firms that are headquartered outside of the contracting parties. Research suggests that firms often reorganize their corporate structure and use

\footnotetext{
${ }^{1}$ I would like to thank three anonymous reviewers for helpful feedback and insightful comments. I am also grateful to Christine Cahill for continued support.

${ }^{2}$ Guzman, 1998

${ }^{3}$ Elkins et al., 2006

(C) The Author(s), 2021. Published by Cambridge University Press. This is an Open Access article, distributed under the terms of the Creative Commons Attribution licence (https://creativecommons.org/licenses/by/4.0/), which permits unrestricted re-use, distribution, and reproduction in any medium, provided the original work is properly cited.
} 
transitional entities to channel investment to third parties. ${ }^{4}$ While firms frequently use foreign subsidiaries for tax avoidance purposes, firms can also use foreign subsidiaries to take advantage of protections provided by BITs. This suggests that the formation of BITs has wide-reaching implications that extend beyond the jurisdiction of the contracting parties. The use of offshore corporate entities, transshipment/conduit investment, and practices like the "Dutch Sandwich" are becoming increasingly widespread. However, the relationship between these practices, international capital flows, and investment treaties is not well understood. This article attempts to examine how indirect FDI flows affect BIT formation and subsequent investment flows.

I argue that BIT formation and choice of specific BIT partners are better understood in the context of indirect ties. FDI flows between a pair of states $i$ and $k$ not only through direct links but also through indirect links. If states $i, j$ have a BIT, and $j$ received FDI from $k$, firms located in $k$ can take advantage of the $i j$ BIT link to channel FDI to $i$ through $j$. This implies that states may seek to form BITs to indirectly access their partner's FDI network. A given state $j$ 's pattern of FDI inflows may increase $j$ 's attractiveness as a potential BIT partner if other states expect to receive indirect FDI flows following the formation of a BIT with $j$. When choosing among potential BIT partners, states thus evaluate not only country-level characteristics but also the characteristics of a state's FDI network. States that receive FDI from a large number of capital exporting states are more likely to be attractive BIT partners due to the potential for indirect FDI flows. This "friends-of-friends" effect is an important aspect of BIT formation that has been overlooked in existing research.

The role of indirect FDI flows suggests a process of BIT formation that has not been considered by other studies: BIT formation is influenced not only by the dyadic or monadic features of states but also by the global pattern of FDI flows. Expected indirect flows create incentives for new BIT formation and result in additional FDI flows. I find that this is reflected both in the higher probability of BIT formation and higher FDI flows among well-connected states following the formation of a BIT. A hierarchy of preferences is suggested: States with many FDI links to capital exporting states will seek out other similarly well-connected partners. Using data on aggregate FDI inflows, I find that states connected by second order links (friends of friends) to capital exporting states tend to receive larger FDI inflows. This pattern applies only to certain types of BITs, however. BITs that include "substantive business requirement" clauses prevent indirect flows by restricting practices involving transshipment investment and treaty shopping. I find that expected FDI flows thus have no effect on the formation of restricted BITs.

This article makes several contributions to the study of BITs and the politics of investment in general. This work is among the first to systematically consider the effects of indirect FDI flows, shedding light on a process of BIT formation and capital movement among states that has been overlooked in previous studies. While indirect investment accounts for 30-50 percent of global FDI flows, ${ }^{5}$ these phenomena are understudied. Thus, while the ownership structure of multinational firms is characterized by everincreasing complexity, this complexity is often not reflected in ongoing FDI research. ${ }^{6}$ The demands of global supply chains provide additional impetus to the development of complicated ownership structures and the use of indirect investment. ${ }^{7}$ The theory and findings in this article thus provide novel information on how firms manage exposure to political risks that grow more complex as global production chains become more widespread. This research examines the role of conduit FDI and shows that indirect FDI flows and the structure of the global BIT network have an important effect on state-level decisions to engage in subsequent integration within the global investment regime. These findings contribute to a more complete understanding of BIT formation and the nature of bilateral economic cooperation more broadly). ${ }^{8}$ These findings also contribute further insights to research on the determinants of FDI flows and generate new information concerning the features and development of the global investment network. ${ }^{9}$

\footnotetext{
${ }^{4}$ Lipsey, 2007

${ }^{5}$ Haberly and Wójcik, 2015

${ }^{6}$ Kerner, 2014

${ }^{7}$ Johns and Wellhausen, 2016; Seabrooke and Wigan, 2017

${ }^{8}$ Elkins et al., 2006; Bubb and Rose-Ackerman, 2007; Hallward-Driemeier, 2009; Simmons, 2014; Arel-Bundock, 2017

${ }^{9} \mathrm{Li}$ and Resnick, 2003; Jensen 2003; Jensen 2006; Jensen 2008; Kerner and Lawrence, 2014
} 
This article proceeds as follows: First, I discuss the existing research on BIT formation and present a theory describing the effect of indirect flows on BIT formation. Second, I use dyadic and monadic analyses to examine the empirical implications of this theory. I find strong evidence in favor of the hypothesis that BITs are more likely to form among well-connected states that receive FDI from capital exporting states. I then present evidence demonstrating that states with second-order FDI links to capital exporters tend to receive more FDI.

\section{Existing Theory}

Existing research on BITs has consistently emphasized the role of BITs as a mechanism of credible commitment. ${ }^{10}$ BITs were negotiated to provide protection to investors and to provide a mechanism of arbitration in cases of host country-investor disputes. Prior to the widespread use of BITs, protection for investors was based in customary international law and the Hull Rule. The Hull Rule states that host countries that engage in expropriation of investment capital must provide "prompt, adequate and effective compensation." While developed states such as the United States sought to codify the Hull Rule as the standard for investments abroad, developing states have resisted such efforts. Throughout the 1970s, developing states have acted in concert at the UN to reject the Hull Rule as a standard for treatment of investors. ${ }^{11}$ Developing states asserted their sovereignty by denying the Hull Rule customary international law status and formulated a standard for investment that emphasized local control over natural resources and the primacy of local legal structures.

At the same time that developing states were collectively asserting their rights with respect to investment in the UN, developing states individually were actively signing BITs with developed states. In doing so, developing states were giving up much of their collective bargaining leverage in the hope of attracting additional FDI. Why did developing states choose to sign BITs? As argued by Vernon and others, economic actors that invest capital abroad often face a time inconsistency problem. ${ }^{12}$ Because FDI often involves the construction of immobile facilities and infrastructure, host nations can change the terms of investment at a later period to collect increased rents. Because FDI capital is less mobile compared to portfolio investment, investors are subject to the whims of the host nation once the investment is made. Investors choose not to invest in host countries where the risk of an obsolescing bargain involving ex-post expropriation or change in the terms of contracts are high.

When host states lack the ability to credibly commit to protect investor property rights through domestic institutions, they may do so by signing BITs with investor home nations. BITs contain a number of mechanisms, including common standards of treatment and dispute settlement mechanisms, designed to eliminate the time inconsistency problem faced by investors. ${ }^{13}$ Host nations that sign BITs do so to credibly guarantee protection of investor property rights. The most important of these mechanisms are clauses providing for neutral third-party arbitration in cases of investor-host disputes. Under the terms of a BIT, investors can bring disputes with host countries to the International Center for Settlement of Investment Disputes (ICSID), which has the authority to issue binding judgments. Investors have used such mechanisms to win compensation from host nations, which have been substantial at times. ${ }^{14}$ While developing states surrender their sovereignty to attract investment, adverse rulings by international arbitration bodies can generate negative effects as well. Such adverse outcome have generated some pushback by developing states. Recent studies of BITs by Allee and Peinhardt (2014) and Simmons (2014) have shown that developing states can successfully resist arbitration requirements under positive economic conditions and are less able to resist such requirements when economic conditions are poor.

Because BITs provide states with a mechanism to provide credible commitment to investors and to reduce risks associated with the time inconsistency problem, a policy of BIT participation has been

\footnotetext{
${ }^{10}$ Vandevelde, 2005; Cho et al., 2016

${ }^{11}$ Guzman, 1998

${ }^{12}$ Vernon, 1971

${ }^{13}$ Muchlinski, 2009

${ }^{14}$ Hallward-Driemeier, 2009
} 
used by developing states to increase FDI inflows. Although the empirical record is mixed, research does show that BIT are effective in attracting FDI. ${ }^{15}$ The usefulness of BIT for FDI promotion also means that states that do not participate in BIT are at a disadvantage in attracting FDI when compared to states that do participate. Elkins et al. (2006) have noted that competitive pressures are important in explaining BIT formation. If developing state A does not have a BIT with developed state B, but developing state $\mathrm{C}$ does, state $\mathrm{C}$ will be a more attractive host for investment from state $\mathrm{B}$ compared to state A. Neumayer and Plümper (2010) show that the effects of competition operates spatially and find that states will emulate the BIT formation behavior of geographically proximate countries.

\section{Indirect FDI}

Although research has linked BITs to diffusion, I argue that an alternative set of mechanisms can account for the formation of BITs. To develop a more effective explanation of BIT formation, it is necessary to take into account the structure of the international FDI network and the role of indirect FDI flows.

While existing research on BITs examines how BITs affect direct FDI flows, the impact of BITs can involve indirect linkages as well. Consider two capital importing states, $i$ and $j$, and a capital exporting state $k$ that sends FDI to $j$, with a $i j$ BIT in place. Although $k$ does not have a direct BIT link with $i$, it does have an indirect link through $j$. Thus, firms based in $k$ can invest in $i$ and take advantage of improved investor protections offered by an $i j$ BIT by first moving capital to state $j$. Although the home country of the ultimate owner of investment in $i$ is not the same as the direct owner, the investment is still protected under the terms of the $i j$ BIT. Many BITs do not make the distinction between ultimate and direct ownership. For example, the BIT between Argentina and Italy classifies protected sources of investment as "any entity ... established in the territory of the Contracting Party". ${ }^{16}$ Any firm located in $j$ would then be able to gain access to the ICSID in the event of a dispute with $i$.

Firms are thus able to take advantage of indirect links when choosing investment hosts. Indirect FDI accounts for an increasingly large portion of international capital flows. ${ }^{17}$ According to some calculations, 30-50 percent of global FDI is accounted for by indirect investment. ${ }^{18}$ Firms seek to take advantage of favorable tax policies, protections of property rights, and international agreements. ${ }^{19}$ To this end, firms route capital through holding companies and special purpose entities (SPEs) located in intermediary countries. One example of this practice is Russian firms engaging in transshipment investment using subsidiaries located in Cyprus to direct investment activities abroad. ${ }^{20}$ Other firms use investment strategies such as the "Dutch Sandwich," where investment between home and host countries is routed through a Dutch subsidiary as a tax avoidance strategy and to access the Netherlands' extensive network of BITs. As Kahale $(2011,1)$ notes, "companies from all over the world having little if anything to do with the Netherlands seek to acquire Dutch nationality to take advantage of the protections offered by Dutch BITs." In a study of internal ownership structure of US multinational firms, Lewellen and Robinson (2013) find that expropriation risks affect firms' ownership structures, where subsidiaries are more likely to form an ownership link when their host countries are connected by BITs.

In part, this pattern is due to the growing complexity of international supply chains. ${ }^{21}$ The needs of vertical production involve subsidiaries in a variety of countries with varying exposures to political risk and patterns of international agreements. Firms may develop more complex ownership structures as a response to varying degrees of expropriation risk in their production network, taking advantage of the global BIT network to shield themselves from expropriation. The growing density of the global BIT

\footnotetext{
${ }^{15}$ Tobin and Rose-Ackerman, 2011; Poulsen, 2013; Neumayer and Spess, 2005

${ }^{16}$ UNCTAD, 1990, 2

${ }^{17}$ Lipsey, 2007

${ }^{18}$ Haberly and Wójcik, 2015

${ }^{19}$ Kalotay, 2012b

${ }^{20}$ Kalotay, 2012a

${ }^{21}$ Johns and Wellhausen, 2016; Seabrooke and Wigan, 2017
} 
network thus facilitates more complicated ownership structures that are necessitated by the requirements of fragmented global production.

This type of behavior has been a point of contention in disputes triggered under BIT provisions. In the Aguas del Tunari v. Bolivia case (ICSID Case No. ARB/02/3), US parent firm Bechtel invoked protections afforded to Dutch investors under the Netherlands-Bolivia BIT. Although Bechtel is based in the United States, Bechtel "migrated" ownership of assets to the Netherlands to take advantage of stronger investor protections provided by the Netherlands-Bolivia BIT. Developing countries have also served as intermediaries for transshipment indirect investment. In part due to its double taxation treaties with the United States and BITs with Austria and Germany, Hungary is used as a hub for indirect FDI flows: In Hungary, outward investment by SPEs accounts for 97 percent of total outward FDI flows. ${ }^{22}$ Much of this investment is directed to Luxembourg and Switzerland, likely as additional steps in a multistage transshipment process.

Indirect FDI flows are likely to play a role in the formation of BITs. A given state is a more attractive partner if a BIT is expected to result in direct FDI flows, indirect FDI flows or both. Indirect flows imply that it is important to consider a potential BIT partner's patterns of FDI inflows. For a firm, a BIT is an opportunity to invest in the partner state as well as to take advantage of a BIT partner's BIT ties to other states. Given FDI flows from $k$ to $j$, capital importing state $i$ may have an incentive to form an $i j$ BIT as $j$ serves as a bridge between $i$ and $k$. With the formation of a $i j$ BIT, firms located in $j$ will be able to engage in transshipment investment to $k$ by channeling funds through $j$. A $i j$ BIT is thus useful for $i$ because it may result in increased indirect FDI flows. This BIT is attractive for $j$ as well: Even though indirect FDI flows are ultimately bound for $i, j$ may still benefit from increased tax revenue, greater access to capital, and other positive spillover effects. If state $i$ receives FDI from state $h$ that lacks a BIT with $j$, state $j$ also stands to benefit from indirect flows if $h$ 's firms channel FDI through $i$.

States that serve as bridges for indirect FDI flows represent an important aspect of the global BIT network. These types of BITs eliminate "structural holes", ${ }^{23}$ or gaps between groups in network structure. The role of indirect flows has implications for the formation of new BITs: When selecting among prospective BIT partners, states are more likely to form BITs with partners that a have a large pool of potential indirect investment. Within the global BIT network, states consider indirect, second-order links (friends of friends) when forming direct, first-order links due to expected future indirect FDI flows. In particular, the potential for indirect flows can be larger when forming BITs with countries that receive FDI from a large number of capital-exporting partners. States should thus prefer to participate in BITs when a large pool of capital would be indirectly accessed through the formation of a BIT. $^{24}$

To understand the process of BIT formation, this logic suggests that it is important to consider the composition of a dyad's disjunctive union; the set of countries sending FDI to states $i$ and $j$, minus the set of shared partners (more formally, if $A$ and $B$ represent the sets of countries that send FDI to $i$ and $j$, the disjunctive union is $(A \cup B)-(A \cap B))$. For a pair of states without a BIT, the disjunctive union is the set of expected dyadic friends of friends after a BIT is formed. If the disjunctive union for a pair of developing states $i j$ consists of many capital exporting states, $i j$ have an incentive to form a BIT due to the potential for indirect FDI flows. Figure 1 illustrates this logic. In this figure, solid lines represent FDI flows, dotted lines represent preferred potential BITs, dashed circles represent capital importing states, and solid circles correspond to capital exporting states. When choosing among potential BIT partners, $i$ is more likely to prefer a BIT with $j$ rather than $k$ since an $i j$ BIT will result in inflows of indirect FDI as firms based in $a, b, c$ send indirect investment to $i$ through $j$. An $i k$ BIT is less likely to result in direct or indirect flows and is thus less likely to form. Likewise, $j$ prefers a BIT with $i$ because this agreement is more likely to result in indirect inflows originating in $x, y, z$. Given the preferences of the two countries, an $i j$ BIT would be preferred to an $i k$ or a $j k$ BIT.

\footnotetext{
${ }^{22}$ Antaloczy and Sass, 2015

${ }^{23}$ Burt, 1995

${ }^{24}$ Although the logic here is focused primarily on second-order connections, this does not preclude longer chains of transshipment investment involving multiple investment hubs. Similar effects can thus be produced through higher order links as well.
} 


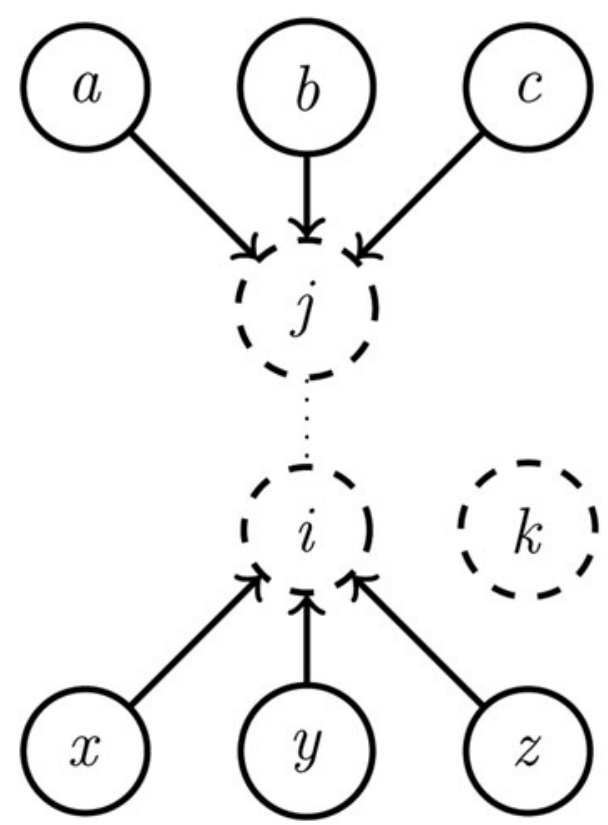

Figure 1. BIT formation and indirect flows.

Why would $i / j$ seek to access indirect FDI from $a, b, c / x, y, z$ rather than forming a BIT with capital exporting states directly? A BIT with an "investment hub" state is more efficient because this BIT grants access to a wide variety of capital exporting countries without the need to negotiate each individual BIT directly. There may also be cases when a developing state is unable to form a direct BIT due to political reasons. Countries may choose not to form BITs with a given prospective partner for a wide variety of reasons, including concerns about democracy, human rights, sanctions or other political and strategic considerations. ${ }^{25}$ Barry and Kleinberg (2015) find evidence for the role of indirect investment and show that firms respond to the imposition of economic sanctions against a host country by shifting assets to "sanction-busting" countries with economic ties to the sanctioned state. Firms may also face backlash at home when directly investing in states that carry negative political baggage, such as ideologically or strategically hostile states. While a direct BIT would be preferred and would eliminate the need for indirect links, in some situations a direct BIT is not feasible and investment is less likely to flow directly. An indirect link thus presents an attractive alternative for both capital importing states that are unable to form a direct BIT with capital exporters, and firms that are prevented by political and economic consideration from investing in a given market directly. Indirect links are thus a second-best alternative to generate FDI flows that would otherwise not occur. Governments may also benefit by serving as FDI "conduits" under some conditions; even purely paper transfers may generate some revenue through taxes and transfer fees. For some smaller offshore financial centers, income generates through registration and transfer fees account for a large share of national income. ${ }^{26}$ Governments may also seek out reputational benefits by participating in many BITs, especially countries that intentionally position themselves as global financial centers.

The composition of a state's BIT network neighborhood affects that state's attractiveness as a BIT partner: BITs are more likely to form in dyads with a high potential for indirect flows. If a given state $i$ receives FDI from a large number of capital exporting countries, other states will be more likely to target $i$ for a new BIT to gain indirect access to $i$ 's network. This relationship should go in both directions in a dyad: in figure $1, i$ has an incentive to access $j$ 's network just as $j$ has an incentive to access $i$ 's

\footnotetext{
${ }^{25} \mathrm{Li}$ and Vashchilko, 2010; Lektzian and Biglaiser, 2013

${ }^{26}$ Sikka, 2003
} 
network. For each state, the utility of forming a BIT with arbitrary state $j$ is a function of expected direct flows and expected indirect flows: $U(B I T)=E\left(f d i_{j}\left(c_{j}\right)\right)+E\left(f d i_{i}\left(\sum c_{s}\right)\right)$, where expected direct/indirect flows $\left(f d i_{j} / f d i_{i}\right)$ are functions of $j$ 's capital endowment, $c_{j}$, and the total capital endowment of states $s$, the set of states accessed through new second-order links formed by a BIT with $j$. A BIT is more likely to form between two states that both receive FDI from a large number of capital exporting states because both states would expect to receive additional FDI inflows. A BIT between a well-connected state and a poorly connected state will be less likely in comparison, with only one state within the dyad expecting to benefit from indirect flows.

We can thus think of three scenarios with increasing likelihoods of BIT formation. The probability of BIT formation is lowest for unconnected capital-poor states with no potential for direct or indirect FDI. Probability of BIT formation is higher in an unbalanced dyad with a connected and unconnected state. While the unconnected state desires the BIT to gain access to second-order FDI links, the connected state expects to receive little or no indirect FDI. The connected state may still choose to form a BIT to receive tax income or registration fees from conduit FDI. An unbalanced BIT may also be useful to connected governments that intentionally pursue a "financial center" strategy and so raise their profile by signing new BITs. The probability of BIT formation in the second scenario is lower than in the third scenario, where both states in the dyad are well connected. Both states have a direct incentive to form a BIT because indirect flows are likely to be bidirectional. This type of BIT closes larger structural holes by connecting discrete clusters of capital-exchanging states. In sum, the potential for BIT formation increases as a function of indirect flows, corresponding to the number of capital exporting countries within a dyad's disjunctive union, the set of friends-of-friends that would be accessed following the creation of a BIT. This logic leads to the following hypothesis:

H1: BITs are more likely form in dyads as the number of FDI senders in the dyadic disjunctive union increases.

Within the BIT network, this hypothesis has implications for "bridging" behavior: States are more likely to participate in BITs when these agreements close structural holes between clusters of states with high capital endowments and capital outflows. In the long run, this process results in two discrete network components: a cluster including large numbers of states with high capital endowments and a cluster composed primarily of poor states.

Another testable implication of these arguments involves the size of dyadic FDI flows following the formation of a BIT. If indirect flows matter, a BIT should result in larger exchanges of capital within a dyad connected by BITs to potential capital exporters. The following hypothesis may be proposed based on this logic:

H2: The positive effect of BITs on dyadic FDI flows increases as the number of FDI senders in the dyadic disjunctive union increases.

The effect of indirect flows should also be reflected on the monadic level. It is possible to consider a state's FDI inflows as being composed of direct and indirect flows. While characteristics, such as capital endowments and FDI outflows, of direct, first-order BIT partners affect the size of direct flows, characteristics of second-order FDI senders should affect indirect flows. States connected through secondorder links to countries with high capital endowments are thus more likely to receive larger FDI inflows. This implies the following hypothesis:

H3: States will receive more FDI inflows as the number of second-order FDI senders accessed through BIT partners increases.

These hypotheses have several implications for the evolution of the global BIT network and patterns of FDI flows. In the long-run, the process of BIT formation should eliminate gaps between communities of states and the global BIT network should thus grow increasingly dense over time. Indirect 
flows also imply a hierarchy of preferences involved in BIT formation. Well-connected states with links to capital exporters will be sought after as targets for new treaties. BITs will thus be most likely to form among pairs of well-connected states. States lacking ties to capital exporters will find it more difficult to form BITs and will be effectively prevented from accessing the network of indirect FDI flows. Within the BIT network, some developing states will occupy a more privileged network position and will be more likely to benefit from indirect FDI inflows.

The logic presented in $\mathrm{H} 1$ and $\mathrm{H} 2$ emphasizes the role of indirect flows for BIT formation. However, not all BITs permit claims from firms based in states that are not directly covered by a BIT; BITs may include language to distinguish between direct and ultimate ownership of assets. Some BITs, such as the Ethiopia-Libya BIT, explicitly require firms to have "substantial business activity" within the territory of the contracting parties to be eligible to claim BIT protections. An additional restriction involves a denial of benefits clause to indicate that firms' activity will not be covered under the terms of the BIT if the substantial business activity requirement is not met. These types of BITs are designed to prevent firms from claiming BIT protections through SPEs and shell corporations when engaging in indirect investment. A substantial business activity requirement, with or without a denial of benefits clause, ensures that the legal definition of investors is not extended to SPEs registered in the territory of the contracting parties.

While some governments may seek out indirect FDI, others erect barriers to indirect investment through restrictive BITs. States may be motivated to limit indirect FDI as an attempt to reduce their exposure to arbitration and dispute settlement risk. It is unclear, however, whether indirect FDI carries a qualitatively different arbitration risk for host states compared to direct FDI. Research suggests that governments pursue more restricted BITs as a response to negative experiences with arbitration. ${ }^{27}$ This not limited to indirect investment only because arbitration claims by firms with less complex ownership structures produce similar reactions among host countries. Ex-ante and without any experience with costly arbitration, it is unlikely that host governments discriminate between direct and indirect FDI. To the extent that governments sign BITs to promote investment, government would likely welcome FDI regardless of the investing firm's ultimate ownership location. States may thus favor or disfavor indirect FDI flows as a function of their past experiences with arbitration and overall evaluation of arbitration risk, although I expect a sufficiently large number of states to favor indirect FDI flows to positively affect BIT formation. Although questions about the broader use of restrictive BITs are outside the scope of the article, the fact that some BITs are designed to prevent indirect flows offers another useful test of the theoretical mechanisms. To the extent that indirect FDI matters for BIT formation, disjunctive FDI outflows should have no effect on the formation of BITs that include clauses requiring substantial business activity. This logic suggests the following hypothesis:

H4: Disjunctive FDI senders have no effect on the formation of BITs with substantial business activity requirements.

\section{Evidence}

To examine if the empirical record supports the hypotheses proposed in the preceding text, I use data on BITs and bilateral FDI flows ${ }^{28}$ from the UN Committee on Trade and Development (UNCTAD). These data cover the period 2001-12, with a BIT coded as a binary variable that is equal to 1 if two states in a dyad signed a BIT in a given year and for all subsequent years, and 0 otherwise. I proceed in two steps: I first examine the effects of indirect flows on BIT formation. I then examine the effect of BITs on FDI flows. Lastly, I examine the effects of second-order FDI on monadic FDI inflows.

My dependent variable is BIT formation, a binary variable equal to 1 in a dyad-year when a BIT is formed and 0 otherwise. To examine H1, I use the number of capital exporting states in each dyad's disjunctive union, Disjunctive Investors, as my key independent variable. Using bilateral FDI data, I identify all countries that sent FDI to countries $i$ and $j$ in year $t$ for each $i, j$ dyad. I then count the

\footnotetext{
${ }^{27}$ Thompson et al., 2019

${ }^{28}$ http://unctad.org/en/Pages/DIAE/FDI\%20Statistics/FDI-Statistics-Bilateral.aspx.
} 
number of countries in the disjunctive union, the set of new, nonoverlapping, capital exporting states that would be accessed through a BIT. To account for outliers, I take the natural log of this variable. I expect higher disjunctive investors to have a positive effect on BIT formation.

I use several additional independent variables identified by previous research as predictors of dyadic BIT formation. Existing literature on BIT formation points to the importance of competitive pressures. As Elkins et al. (2006) show, a popularity effect operates where developing states face greater pressure to form BITs with capital exporting states that are participants in a large number of BITs with other developing states. This popularity effect corresponds to a network process of preferential attachment where actors with a large number of links (high degree) are more likely to form subsequent links. To control for this process, I include a variable corresponding to a state $i$ and $j$ 's logged number of BITs (logged degree). ${ }^{29}$ I expect that states will be more likely to form links with BIT partners that already participate in a large number of BITs and I thus expect a positive coefficient for these variables.

Research also suggests that geographic distance plays a role in BIT formation: ${ }^{30}$ Geographically proximate states are more likely to form BITs compared to geographically distant states. I include a measure of geographic distance that corresponds to the kilometer distance between capital cities and I expect distance to have a negative effect on BIT formation. Ideologically proximate countries may also be more likely to form BITs. I measure ideological similarity as similarity in regime types and I include variables that measures democracy in a given dyad. Using Polity IV data, I include autocracy-democracy scores for both states in the dyad. States with similar regime types may be more likely to participate in BITs and I expect positive coefficients for this variable.

Trade and trade-related issues may also play a role in BIT formation. ${ }^{31}$ A pair of states that engage in common trade may be more likely to form a BIT to deepen economic cooperation. To measure the effects of trade, I control for the logged sum of exports and imports in a given dyad and I expect this variable to be positively correlated with BIT formation. Data on directed trade is drawn from the Correlates of War project. Market size and economic growth of potential BIT partners may also affect the decision to form a BIT and so I control for logged GDP $\mathrm{GL}^{32}$ and per capita GDP growth for states $i$ and $j$. I anticipate that rich, growing states are more likely to export capital and are thus more attractive BIT partners. I expect a country's logged GDP and pc GDP growth to be positively associated with BIT formation. Data on GDP and GDP growth comes from the World Bank World Development Indicators. Following Carter and Signorino (2010), I include time, time ${ }^{2}$, and time ${ }^{3}$ to control for the impact of time on BIT formation hazard.

Lastly, I use data on BIT content to examine H4. Using the UNCTAD BIT database, I identify all BITs that include a substantial business activity requirements and use these BITs as an alternative dependent variable. I expect disjunctive investors to have no effect on the formation of these types of BITs. I estimate a series of logit models with robust standard errors clustered by dyad: First, I estimate a baseline model with all covariates. Next, I use unrestricted BITs as the dependent variable in model 2. Model 3 uses restricted BITs (substantial business activity requirement) as the dependent variable. I also use several additional models as robustness checks. Developed major economies also receive investment from a large variety of states. BITs with these states may be motivated primarily by direct FDI, not indirect FDI. To account for this possibility, I limit the sample to South-South dyads only, using OECD membership to identify developing states. ${ }^{33}$ Model 4 presents these estimates. I also examine the extent to which these results are driven by countries that explicitly position themselves as tax havens and financial centers. To evaluate this possibility, I exclude all dyads involving Switzerland, Ireland, Cyprus, the Netherlands, and Luxembourg. ${ }^{34}$ Model 5 reports estimates using this sample. The results of these models are presented in table 1.

\footnotetext{
${ }^{29}$ Degree is logged to account for the presence of outliers with very high degrees.

${ }^{30}$ Neumayer and Plümper, 2010

${ }^{31}$ Tobin and Busch, 2010

${ }^{32} \mathrm{GDP}$ measured in constant 2000 dollars.

${ }^{33}$ These results are unaffected by use of alternative indicators for development, such as World Bank income status classifications.

${ }^{34}$ Some smaller financial centers such as Hong Kong, Cayman Island, and the Bahamas are already excluded from analysis due to missing data in the covariates.
} 
Table 1. Logit BIT formation models.

\begin{tabular}{|c|c|c|c|c|c|}
\hline & Model 1 & Model 2 & Model 3 & Model 4 & Model 5 \\
\hline \multirow[t]{2}{*}{ Disjunctive Investors } & $.214^{\star \star \star}$ & $.180^{\star \star}$ & .011 & $.313^{\star * *}$ & $.227^{\star \star \star}$ \\
\hline & $(.07)$ & (.08) & (.08) & $(.10)$ & $(.07)$ \\
\hline \multirow[t]{2}{*}{ Distance } & $-.000^{\star \star \star}$ & $-.000^{\star \star \star}$ & $-.000^{\star \star \star}$ & $-.000^{\star \star \star}$ & $-.000^{\star \star *}$ \\
\hline & $(.00)$ & $(.00)$ & $(.00)$ & $(.00)$ & $(.00)$ \\
\hline \multirow[t]{2}{*}{ In BITs 1} & $.678^{\star \star \star}$ & $.745^{\star \star \star}$ & $.563^{\star \star \star}$ & $.851^{\star \star \star}$ & $.711^{\star \star \star}$ \\
\hline & $(.08)$ & $(.09)$ & $(.14)$ & $(.12)$ & $(.09)$ \\
\hline \multirow[t]{2}{*}{ In BITs 2} & $.398^{\star \star \star}$ & $.341^{\star \star *}$ & $.289^{\star \star *}$ & $.522^{\star \star \star}$ & $.377^{\star \star *}$ \\
\hline & $(.06)$ & $(.07)$ & (.14) & $(.08)$ & $(.06)$ \\
\hline \multirow[t]{2}{*}{ Democracy 1} & $-.504^{\star \star \star}$ & $-.652^{\star \star \star}$ & -.221 & $-.714^{\star \star \star}$ & $-.500^{\star \star \star}$ \\
\hline & (.15) & (.16) & $(.29)$ & $(.20)$ & $(.15)$ \\
\hline \multirow[t]{2}{*}{ Democracy 2} & -.201 & -.239 & -.105 & $.349^{\star}$ & -.204 \\
\hline & (.15) & $(.16)$ & $(.24)$ & (.19) & $(.15)$ \\
\hline \multirow[t]{2}{*}{ pc GDP 1} & $-.130^{\star \star}$ & $-.121^{\star \star}$ & -.075 & $-.217^{\star \star}$ & $-.128^{\star \star}$ \\
\hline & $(.06)$ & $(.06)$ & (.08) & (.09) & $(.06)$ \\
\hline \multirow[t]{2}{*}{ pc GDP 2} & .056 & .065 & .104 & $.147^{\star \star}$ & .056 \\
\hline & $(.05)$ & $(.05)$ & $(.09)$ & $(.07)$ & $(.05)$ \\
\hline \multirow[t]{2}{*}{ Trade } & .063 & .064 & .101 & $.174^{\star \star \star}$ & $.075^{\star}$ \\
\hline & $(.04)$ & $(.04)$ & $(.06)$ & $(.05)$ & $(.04)$ \\
\hline \multirow[t]{2}{*}{ In Growth 1} & .107 & .072 & $.262^{\star \star}$ & $.361^{\star \star}$ & .083 \\
\hline & $(.09)$ & $(.09)$ & (.11) & (.16) & $(.08)$ \\
\hline \multirow[t]{2}{*}{ In Growth 2} & $.242^{\star \star}$ & $.271^{\star \star}$ & $.291^{\star \star \star}$ & -.020 & $.248^{\star \star}$ \\
\hline & (.11) & (.11) & (.10) & (.13) & (.11) \\
\hline \multirow[t]{2}{*}{$t$} & $-17.855^{\star \star \star}$ & $-19.936^{\star \star \star}$ & $-3.771^{\star \star \star}$ & $-11.167^{\star}$ & $-18.624^{\star \star \star}$ \\
\hline & (3.13) & (3.49) & $(1.06)$ & (6.75) & $(3.20)$ \\
\hline \multirow[t]{2}{*}{$t^{2}$} & $.776^{\star \star \star}$ & $.868^{\star \star \star}$ & $.167^{\star \star \star}$ & .447 & $.811^{\star \star *}$ \\
\hline & (.14) & (.16) & (.05) & (.32) & (.15) \\
\hline \multirow[t]{2}{*}{$t^{3}$} & $-.011^{\star \star \star}$ & $-.012^{\star \star \star}$ & $-.002^{\star \star \star}$ & -.006 & $-.012^{\star \star \star}$ \\
\hline & $(.00)$ & $(.00)$ & $(.00)$ & $(.00)$ & $(.00)$ \\
\hline \multirow[t]{2}{*}{ Constant } & $128.816^{\star \star \star}$ & $143.877^{\star \star \star}$ & $20.240^{\star \star}$ & $82.883^{*}$ & $134.337^{\star * *}$ \\
\hline & $(22.79)$ & $(25.36)$ & $(7.92)$ & $(47.38)$ & $(23.27)$ \\
\hline $\mathrm{N}$ & 110475 & 110475 & 110475 & 68319 & 104106 \\
\hline$\chi^{2}$ & 782.084 & 702.121 & 312.117 & 382.518 & 714.631 \\
\hline
\end{tabular}

${ }^{\star} p<0.10 ;{ }^{\star \star} p<0.05 ;{ }^{* \star \star} p<0.01$.

Overall, these results provide support for H1. I find that disjunctive investors have a positive and significant effect on the likelihood of BIT formation. States are consistently more likely to form BITs when average number of disjunctive investors is high. Doubling the amount of disjunctive investors in a dyad increases the likelihood of a BIT by approximately 200 percent. Figure 2 plots the predicted probabilities generated using estimates from model 1 , keeping all other variables at their means. Compared to a dyad without any potential for indirect flows, a dyad with maximum observed disjunctive investors is nearly three times more likely to participate in a BIT. The effect of indirect flows is thus 


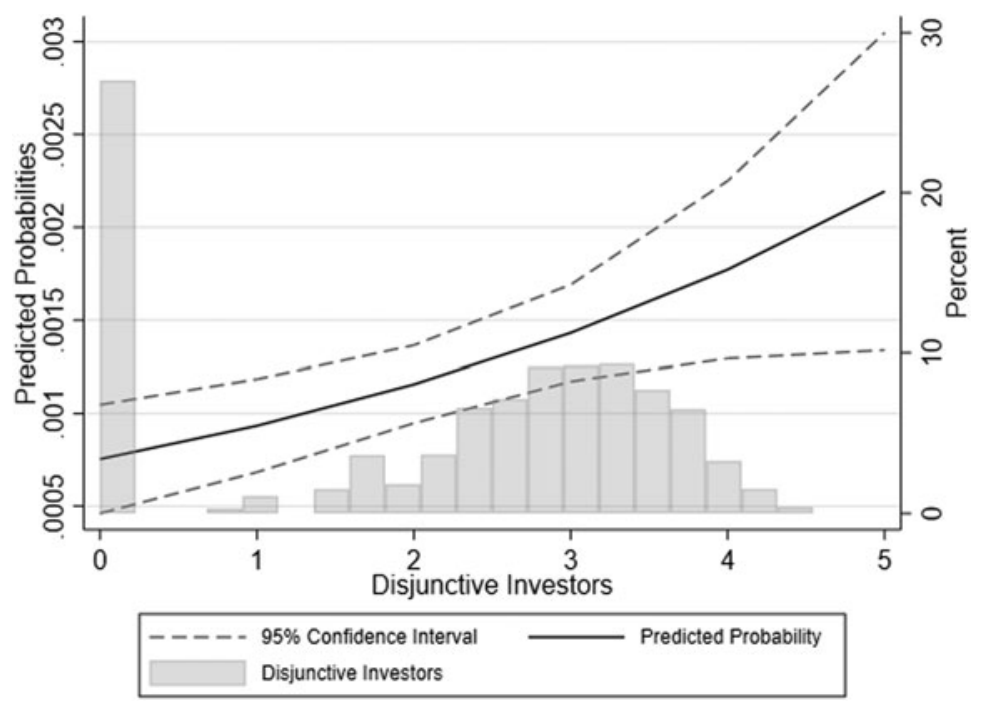

Figure 2. Predicted probabilities.

substantively important and can significantly affect state-level preferences for BIT formation. Furthermore, model 3 indicates that disjunctive investors have no effect on the formation of BITs with substantial business activity requirements. Disjunctive investors have a positive effect only on the formation of unrestricted BITs that permit indirect FDI flows. This provides additional evidence in favor of the theoretical logic: The potential for indirect flows has a positive effect only on the formation of BITs that protect investment directly owned by SPEs and shell companies. Which countries are more likely to form restricted BITs? Although restricted BITs are considerably less common than unrestricted BITs, unrestricted BITs are formed at higher rates in North-South dyads (six times more unrestricted than restricted) than in South-South dyads (four times more unrestricted than restricted). Developed capital exporters may thus prefer to sign unrestricted BITs, using their economic power to accomplish this goal. Some developing countries, especially those that have experienced high costs in arbitration or anticipate high arbitration costs, ${ }^{35}$ may choose to pursue restricted BITs to prevent indirect flows. These BITs would be easier to adopt in South-South dyads due to greater bargaining parity.

The additional robustness checks also provide evidence in favor of the theory. BIT formation appears to be influenced by indirect FDI flows in dyads composed of developing countries only. Because the likelihood of receiving direct FDI is much lower in South-South dyads, the widespread prevalence of these agreements has been an ongoing puzzle in the BIT formation literature. ${ }^{36}$ Results in model 4 suggest that South-South BITs may be motivated in part by access to indirect FDI flows. ${ }^{37}$ This provides additional support in favor of the proposed mechanisms. The substantive results are also unaffected by exclusion of financial center countries. Because the observed relationships are not due to financial centers alone, this suggests that global value chains involving a larger set of states likely play a role in indirect FDI and BIT formation.

The effects of other controls are consistent with expectation. As expected, states are less likely to form BITs with geographically distant states. In line with results from previous studies, ${ }^{38}$ BITs are more likely to form in dyads where states already participate in BITs. Trade also has a positive and

\footnotetext{
${ }^{35}$ Thompson et al. 2019

${ }^{36}$ Poulsen 2010; Jandhyala et al. 2011

${ }^{37}$ Although the point estimates in model 4 are larger than model 1, these estimates are also noisier, as evidenced by the larger standard error. These effects are also statistically indistinguishable: A Z-test for the difference of the two coefficients returns a Z-score of .819. This suggests that developing countries are at least as important as developed countries in serving as hubs for conduit FDI.

${ }^{38}$ Elkins et al. 2006
} 
significant effect on BIT formation. Surprisingly, democracy appears to have a negative effect on BIT formation.

While these results provide evidence in favor of the indirect flows mechanism, it is unclear if it is specifically the expectation of increased investment that generates new BITs. Given H2, we should expect to observe larger FDI flows following the formation of a BIT in a dyad with BIT links to capital exporting states. To examine these hypotheses, I use UNCTAD data on bilateral FDI flows and construct a model based on the gravity approach. ${ }^{39}$ As my dependent variable, I use the logged sum of FDI inflows within the dyad: $\ln$ (inflows from $i$ to $j+$ inflows from $j$ to $i$ ). Because the theoretical logic is agnostic about the direction of FDI flows once a BIT is formed, I focus on the total volume of FDI activity in a dyad. Using the gravity model approach, I model dyadic FDI flows as a function of logged economic size of the states in the dyad as well as the political "distance" between states.

The key independent variable in this analysis is the interaction between an indicator variable equal to 1 if a BIT is present and 0 otherwise, and disjunctive investors. Given the theoretical expectation, I expect a positive effect for this interaction term. As before, I disaggregate BITs into restricted BITs with substantial business requirements, and unrestricted BITs. I expect the interaction term between restricted BITs and disjunctive investors to be unrelated to dyadic FDI flows. To measure the economic size of states within a dyad, I use logged pc GDP and pc GDP growth. States with larger, growing economies are more likely to attract investment and so I expect these variables to be positively related to FDI flows. I also include logged trade because trade may result in greater dyadic FDI flows. The number of BITs that a state participates in may also affect FDI flows; I include the logged sum of BITs (degree) for state 1 and state 2. I expect FDI flows to be larger in dyads where dyad members participate in a large number of BITs. To account for political distance, I include the indicator for joint democracy used in models 1-3. Democracies may be more likely to invest in ideologically proximate states with more effective institutions, and I expect joint democracy to be positively associated with FDI flows.

I estimate a panel regression model with Driscoll-Kraay standard errors ${ }^{40}$ and dyad and year fixed effects. I proceed as follows: First, I estimate a model with all variables and all BITs. I interact the disjunctive wealth variable with BITs in in model 7. I then disaggregate BITs and interact disjunctive wealth with restricted and unrestricted BITs in model 8. Models 9 and 10 present estimates using South-South dyads only, and with financial centers excluded, respectively. Results are presented in table 2 .

The results of the models in table 2 provide evidence in favor of the mechanisms proposed in this article. These results show that it is indeed the prospect of indirect FDI flows that contributes to BIT formation. When a new BIT connects two states tied by BITs to capital exporting states, this BIT results in considerable new FDI flows. Figure 3 plots the marginal effects of unrestricted BITs across observed values for disjunctive wealth, using estimates from model 6. At lower levels of disjunctive investors, marginal effect estimates in figure 3 are less precise. This higher variance in the left tail is a function of patterns of BIT formation. Figure 4 displays distributions of disjunctive investors for dyads with and without BITs. As the figure and estimates in table 1 show, BIT-forming dyads tend to have more disjunctive investors. Results are thus more consistent in BIT dyads at more commonly observed levels of disjunctive investors.

Figure 3 indicates that BITs can result in significant increases in FDI flows. In a dyad with the maximum observed value of disjunctive wealth, a BIT can increase dyadic FDI flows by as much as 275 percent. Indirect flows thus appear to play an important role in FDI flows and can potentially result in significant international movements of capital. What are some "typical" countries that sign BITs to access indirect FDI? Among BIT dyads with highest bilateral FDI flows and most disjunctive investors are North-South dyads like Italy-Jordan, France-Morocco, and Netherlands-China. However, some South-South dyads such as China-Mauritius and India-Indonesia also have high bilateral flows and many disjunctive investors. This suggests that while some low-income developing countries

\footnotetext{
${ }^{39}$ Matyas, 1997

${ }^{40}$ Driscoll-Kraay standard errors are robust to arbitrary autocorrelation, heteroskedasticity, and cross-sectional correlation (Driscoll and Kraay, 1998).
} 
Table 2. Bilateral FDI flows models.

\begin{tabular}{|c|c|c|c|c|c|}
\hline & Model 6 & Model 7 & Model 8 & Model 9 & Model 10 \\
\hline \multirow[t]{2}{*}{ BIT } & .163 & -.716 & & -.376 & -.776 \\
\hline & $(.28)$ & (.61) & & (.64) & $(.58)$ \\
\hline \multirow[t]{2}{*}{ BIT $\times$ Disjunctive Investors } & & $.244^{\star \star}$ & & $.314^{\star *}$ & $.261^{\star \star}$ \\
\hline & & $(.12)$ & & $(.15)$ & $(.11)$ \\
\hline \multirow[t]{2}{*}{ Unrestricted BIT } & & & -.645 & & \\
\hline & & & (.56) & & \\
\hline \multirow{2}{*}{$\begin{array}{l}\text { Unrestricted BIT × } \\
\text { Disjunctive Investors }\end{array}$} & & & $.245^{\star \star}$ & & \\
\hline & & & $(.11)$ & & \\
\hline \multirow[t]{2}{*}{ Restricted BIT } & & & -.074 & & \\
\hline & & & $(1.89)$ & & \\
\hline \multirow{2}{*}{$\begin{array}{l}\text { Restricted BIT } \times \text { Disjunctive } \\
\text { Investors }\end{array}$} & & & -.054 & & \\
\hline & & & (.49) & & \\
\hline \multirow[t]{2}{*}{ Disjunctive Investors } & $.229^{\star \star}$ & $.169^{\star \star \star}$ & $.170^{\star \star \star}$ & .132 & $.195^{\star \star}$ \\
\hline & $(.08)$ & (.05) & (.05) & $(.08)$ & $(.07)$ \\
\hline \multirow[t]{2}{*}{ In BITs 1} & .394 & .405 & .416 & $-.655^{\star}$ & .364 \\
\hline & $(.45)$ & $(.45)$ & $(.45)$ & $(.29)$ & $(.41)$ \\
\hline \multirow[t]{2}{*}{ In BITs 2} & .160 & .164 & .166 & .222 & .048 \\
\hline & (.18) & (.18) & (.18) & $(.23)$ & (.18) \\
\hline \multirow[t]{2}{*}{ pc GDP 1} & $2.344^{\star \star \star}$ & $2.296^{\star \star \star}$ & $2.325^{\star \star \star}$ & -.532 & $1.897^{\star \star \star}$ \\
\hline & (.53) & (.52) & $(.52)$ & (1.39) & $(.52)$ \\
\hline \multirow[t]{2}{*}{ pc GDP 2} & $2.523^{\star \star \star}$ & $2.489^{\star \star \star}$ & $2.496^{\star \star \star}$ & $3.888^{\star \star \star}$ & $2.149^{\star \star \star}$ \\
\hline & $(.40)$ & $(.40)$ & $(.40)$ & $(.41)$ & $(.50)$ \\
\hline \multirow[t]{2}{*}{ Democracy 1} & $-.317^{\star}$ & $-.338^{\star}$ & $-.340^{\star \star}$ & -.014 & $-.345^{\star}$ \\
\hline & (.15) & (.15) & (.15) & $(.21)$ & (.16) \\
\hline \multirow[t]{2}{*}{ Democracy 2} & $.355^{\star \star}$ & $.350^{\star *}$ & $.349^{\star \star}$ & .342 & $.426^{\star *}$ \\
\hline & $(.15)$ & (.15) & (.15) & $(.27)$ & $(.15)$ \\
\hline \multirow[t]{2}{*}{ Trade } & $.103^{\star}$ & $.098^{\star}$ & $.099^{\star}$ & .081 & $.170^{\star \star \star}$ \\
\hline & $(.05)$ & $(.05)$ & $(.05)$ & $(.08)$ & $(.05)$ \\
\hline \multirow[t]{2}{*}{ In Growth 1} & $.096^{\star \star \star}$ & $.098^{\star \star \star}$ & $.098^{\star \star \star}$ & $.191^{\star \star \star}$ & $.114^{\star \star \star}$ \\
\hline & $(.02)$ & $(.02)$ & $(.02)$ & $(.04)$ & $(.02)$ \\
\hline \multirow[t]{2}{*}{ In Growth 2} & .032 & .034 & .033 & .053 & .081 \\
\hline & $(.04)$ & (.04) & (.04) & $(.07)$ & $(.05)$ \\
\hline \multirow[t]{2}{*}{ Constant } & $-127.508^{\star \star \star}$ & $-125.110^{\star \star \star \star}$ & $-126.114^{\star \star \star}$ & $-82.925^{\star \star}$ & $-106.845^{\star \star \star}$ \\
\hline & $(18.71)$ & (18.48) & $(18.18)$ & (34.57) & (21.16) \\
\hline $\mathrm{N}$ & 11062 & 11062 & 11062 & 2515 & 9436 \\
\hline Year \& Dyad FE & Y & Y & Y & Y & Y \\
\hline Within $R^{2}$ & .0229 & .0231 & .0232 & .0968 & .0265 \\
\hline
\end{tabular}

${ }^{*} p<0.10 ;{ }^{* *} p<0.05 ;{ }^{* * *} p<0.01$. 


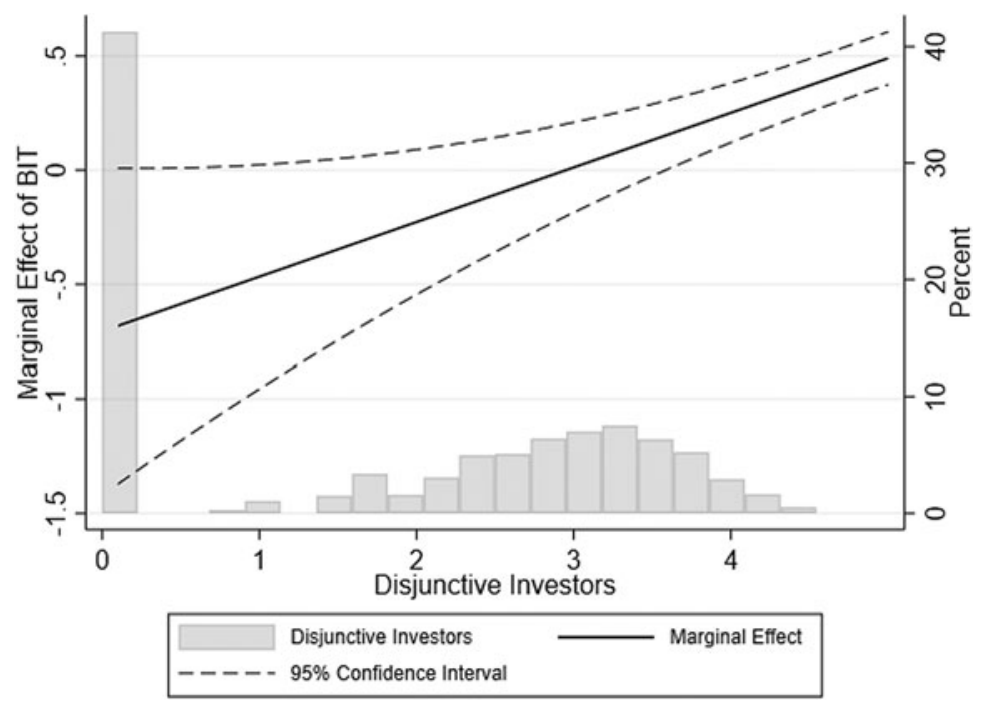

Figure 3. BIT marginal effects.

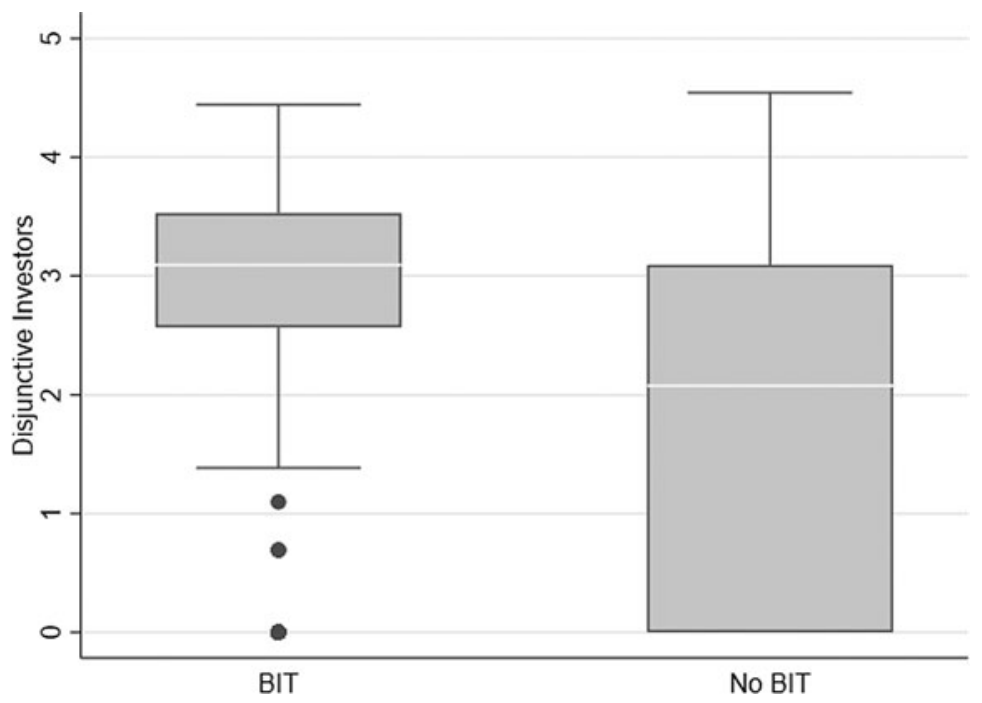

Figure 4. Disjunctive investors distribution.

may seek to access indirect FDI from developed states, middle-income countries such as India or Indonesia may also pursue BITs with other developing states for this purpose.

This evidence shows a pattern that is highly consistent with expectations and provides support for an explanation of FDI based on indirect flows. Consistent with previous results, model 8 estimates show that BITs with substantial business requirements have no effect on FDI flows. The robustness checks are substantively similar to other estimates. Indirect FDI is associated with larger capital exchanges in South-South dyads. This provides additional support to the notion that South-South BITs are generated in part as a function of expected indirect flows. The substantive results are also unaffected when dropping financial center countries from the sample. An important aspect of bilateral FDI data involves a large number of missing dyadic observations. I examine the role of missing data using a series of analyses presented in the appendix. I find that the substantive results in table 2 are unaffected when missing data is imputed with different approaches. 


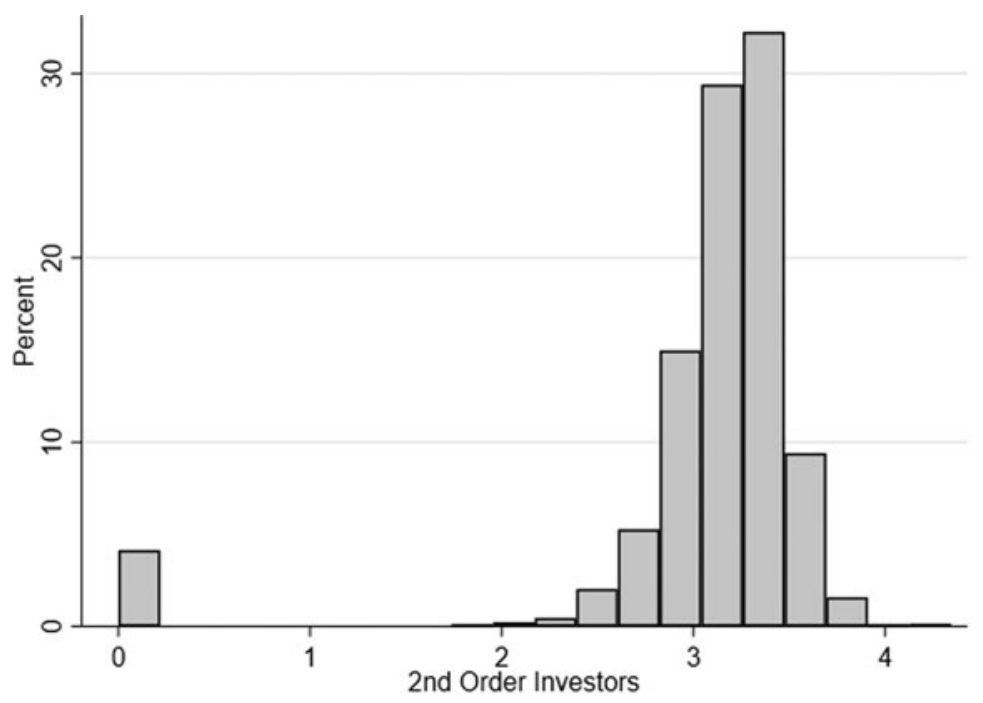

Figure 5. Monadic disjunctive investors distribution.

While analyses of dyadic FDI flows in table 2 provide further evidence in favor of the indirect flows hypotheses, the logic of indirect flows has implications for studies of FDI at the country-year level of analysis. If indirect FDI flows matter for states, H3 suggest that the effect of indirect flows should be observable for overall FDI inflows. To examine the impact of indirect flows on FDI inflows for each state, it is necessary to examine characteristics of second-order links (friends of friends) within the global BIT network. To this end, I conduct an additional set of analyses, using country-year data on logged FDI inflows as my dependent variable. As my key independent variable, I calculate the average number of second-order FDI senders accessed through first order BIT links. In other words, this variable counts the average number of states that send FDI to $i$ 's BIT partners. This measure is consistent with the logic of H3: States that are on average indirectly tied by BIT links to many capital exporters are more likely to receive indirect FDI flows.

This is an indirect measure because constructing a direct measure of indirect flows would require extensive data on firm ownership structure. Nevertheless, this measure likely captures the dynamics predicted by the theory. It is reasonable to expect that more indirect flows would result from ties to well-connected partners that receive FDI from a large number of states. Figure 5 plots this variable's distribution. On average, states connect to approximately twenty second-order FDI senders through their first-order BIT links. The overall distribution is similar to the dyadic measure displayed in figures 2 and 3. This lends some evidence to the notion that these variables are measuring similar underlying concepts. Given the expectations in H3, I expect to find a positive relationship between FDI inflows and second-order investors. Only unrestricted BIT links are expected to have an effect on FDI inflows. To this end, I distinguish between the number of second-order FDI senders accessed through unrestricted BITs, as well as the number of second-order FDI senders access using restricted links.

I also include a set of covariates identified as important in previous studies of FDI inflows. I include measures for pc GDP and pc GDP growth. I control for trade (exports + imports as a percentage of GDP) and logged inflation (consumer prices). The preceding economic measures are drawn from the World Bank WDI dataset. I also control for political factors and include the Polity IV measure of democracy. Lastly, I control for a country's logged number of BITs (degree).

Using these measures, I estimate a panel regression model and include year and country fixed effects. I estimate four models: I use overall second order investors as my key independent variable in model 7, and include second-order investors for restricted and unrestricted BIT links in model 8. I then reestimate these models while limiting the sample to developing countries only, as before using OECD membership to identify developed/developing states. The results are presented in table 3 . 
Table 3. Monadic FDI models.

\begin{tabular}{|c|c|c|c|c|}
\hline & Model 11 & Model 12 & Model 13 & Model 14 \\
\hline \multirow[t]{2}{*}{ 2nd Order Investors } & .131 & & $.222^{\star \star}$ & \\
\hline & (.09) & & $(.08)$ & \\
\hline \multirow[t]{2}{*}{ 2nd Order Investors Unrestricted } & & $.172^{\star \star}$ & & $.219^{\star \star}$ \\
\hline & & $(.07)$ & & (.08) \\
\hline \multirow[t]{2}{*}{ 2nd Order Investors Restricted } & & $-.114^{\star \star}$ & & $-.133^{\star \star \star}$ \\
\hline & & $(.04)$ & & $(.03)$ \\
\hline \multirow[t]{2}{*}{ Democracy } & .024 & .021 & .036 & .034 \\
\hline & (.03) & (.03) & (.03) & $(.03)$ \\
\hline \multirow[t]{2}{*}{ Trade } & .070 & .089 & -.064 & -.052 \\
\hline & $(.20)$ & $(.21)$ & $(.31)$ & $(.32)$ \\
\hline \multirow[t]{2}{*}{ Inflation } & .172 & .169 & .235 & .240 \\
\hline & $(.15)$ & (.15) & $(.17)$ & $(.17)$ \\
\hline \multirow[t]{2}{*}{ Growth } & $.065^{\star}$ & $.067^{\star}$ & .027 & .032 \\
\hline & $(.04)$ & $(.03)$ & $(.04)$ & $(.04)$ \\
\hline \multirow[t]{2}{*}{ In pc GDP } & $1.831^{\star \star}$ & $1.833^{\star *}$ & .863 & .821 \\
\hline & (.69) & (.70) & (.69) & $(.71)$ \\
\hline \multirow[t]{2}{*}{ Total BITs } & $-.269^{\star \star}$ & -.182 & $-.364^{\star \star}$ & $-.296^{\star}$ \\
\hline & $(.12)$ & (.11) & (.13) & (.14) \\
\hline \multirow[t]{2}{*}{ Constant } & -25.715 & -26.029 & -2.026 & -1.132 \\
\hline & $(16.38)$ & $(16.63)$ & $(15.17)$ & $(15.53)$ \\
\hline $\mathrm{N}$ & 1330 & 1330 & 926 & 926 \\
\hline Year and Country FE & $\mathrm{Y}$ & $\mathrm{Y}$ & Y & Y \\
\hline Within $R^{2}$ & .4054 & .4087 & .4092 & .4130 \\
\hline
\end{tabular}

${ }^{\star} p<0.10 ;{ }^{\star \star} p<0.05 ;{ }^{\star \star \star} p<0.01$

These results provide further support for H3. The pattern uncovered in table 3 is consistent with preceding analyses: Second-order ties to capital exporting states are associated with increased monadic FDI flows. The pattern of results is consistent with the theoretical logic, showing that it pays to have second-order links to wealthy, capital-exporting states. While unrestricted second-order FDI is associated with increased inflows, more second-order FDI ties accessed through restricted BIT links are associated with decreasing inflows. This evidence is consistent with the notion that restricted BITs are barriers for indirect FDI compared to unrestricted BITs. These relationships are more pronounced for developing countries. This finding makes sense: Additional protections offered to firms by BITs should matter more for developing countries because developing countries are less likely to provide robust protections to foreign capital through domestic institutions. Overall, evidence provides consistent support for $\mathrm{H} 1-\mathrm{H} 3$ and points to the important role played by indirect flows in affecting the likelihood of BIT formation and the inflows of FDI to developing states.

\section{Conclusion}

In this article I have argued that indirect FDI plays an important role for BIT formation and for FDI inflows. BITs are a central feature of the international investment regime; considering the emphasis placed on BITs by the UN, BITs will continue to be an important mechanism for governing bilateral 
investment. This article shows that the decision to form a BIT is not influenced by monadic or dyadic factors alone but by the structure of the global BIT network. These network effects play an important role in BIT formation.

The evidence presented here has implications for the ongoing development of the global BIT network. Evidence shows that states engage in a particular type of "bridging" behavior: Pairs of states are more likely to close structural holes when the resulting BIT eliminates gaps between groups of capital exporting states. However, structural holes are more likely to persist among groups of developing states. BITs are unlikely to form when these treaties do not result in new indirect investment. Developing countries with few connections to wealthy capital exporters are thus likely to remain locked out the global network of BITs and are less likely to experience investment inflows. Further research is needed to explore the hierarchy of preferences among states and how these factors affect and are affected by a state's development status. Furthermore, it is necessary to understand how firms use the legal protections gained through indirect investment. Research on the determinants of ICSID cases may shed additional lights on these processes.

The role of indirect flows raises further questions for FDI research using balance of payments data. The key implication of this research is that indirect FDI flows matter and likely compose a nonnegligible proportion of total FDI inflows and outflows in both developed and developing countries. The fact that the direct investment owner is often different from the ultimate owner implies that data on FDI flows relying purely on balance of payments information may lead to distortions and incorrect inferences. ${ }^{41}$ If country $i$ channels investment to $j$ through country $k$, FDI inflows data may falsely attribute asset ownership to country $k$. Researchers must therefore remain sensitive to the role of indirect FDI flows when examining the causes or effects of international capital flows.

The nature of indirect flows show that network effects matter with respect to international institutions and the evolution of global cooperation. The role of second-order ties has implications for other types of international flows, such as a trade. The reexportation of products and the pattern of global PTAs may lead to a "spaghetti bowl" 42 network pattern, or may result in an alternative set of network structures. Growing complexity of global supply chains also implies that firms may develop more complex ownership structures and patterns of input production to take advantage of dense networks of global agreements. It may be useful to consider if such processes operate with respect to other types of economic processes, such as financial flows or international migration in future research. A more complete understanding of the operation of network processes such as triadic closure or preferential attachment can shed light on broad questions concerning the spread of international agreements and the success of global governance strategies.

\section{Appendix}

I conduct a series of additional analyses to examine how missing data patterns affect the results in table 2. Because the UNCTAD bilateral FDI data has a considerable amount of incomplete observations that are dropped when using listwise deletion, I attempt to address this problem by using multiple imputation techniques to impute missing observations for bilateral FDI flows. ${ }^{43}$ Using chained equations, I generate ten samples for the imputation procedure and estimate missing values using a truncated regression model. Table 4 reports estimates from models using these imputed data. As an alternative approach, I reestimated table 2 after replacing all missing bilateral FDI observations with zero. These results are presented in table 5. Overall, these models generate the same substantive results as the models in table 2. This suggests that patterns of data missingness do not appear to affect the substantive conclusions presented in the main text.

\footnotetext{
${ }^{41}$ Lipsey 2007

${ }^{42}$ Baldwin, 2006

${ }^{43}$ Most missing observations are in dyads involving geographically distant developing countries that are unlikely to exchange FDI.
} 
Table 4. Imputed analyses.

\begin{tabular}{|c|c|c|c|c|}
\hline & Model 1 & Model 2 & Model 3 & Model 4 \\
\hline \multirow[t]{2}{*}{ BIT } & $-.380^{\star \star}$ & & $-.352^{\star \star}$ & $-.391^{\star \star}$ \\
\hline & $(.12)$ & & (.15) & (.13) \\
\hline \multirow[t]{2}{*}{ BIT $\times$ Disjunctive Investors } & $.121^{\star \star}$ & & $.127^{\star \star}$ & $.127^{\star \star}$ \\
\hline & $(.03)$ & & $(.04)$ & $(.03)$ \\
\hline \multirow[t]{2}{*}{ Unrestricted BIT } & & $-.387^{\star \star}$ & & \\
\hline & & $(.12)$ & & \\
\hline \multirow[t]{2}{*}{ Unrestricted BIT $\times$ Disjunctive Investors } & & $.126^{\star \star}$ & & \\
\hline & & $(.03)$ & & \\
\hline \multirow[t]{2}{*}{ Restricted BIT } & & -.106 & & \\
\hline & & $(.25)$ & & \\
\hline \multirow[t]{2}{*}{ Restricted BIT $\times$ Disjunctive Investors } & & .058 & & \\
\hline & & $(.07)$ & & \\
\hline \multirow[t]{2}{*}{ Disjunctive Investors } & $.168^{\star \star \star}$ & $.167^{\star \star \star}$ & $.142^{\star \star \star}$ & $.170^{\star \star *}$ \\
\hline & $(.02)$ & $(.02)$ & $(.01)$ & $(.02)$ \\
\hline \multirow[t]{2}{*}{ In BITs 1} & -.097 & -.098 & $-.143^{\star}$ & -.093 \\
\hline & $(.05)$ & $(.05)$ & $(.05)$ & $(.05)$ \\
\hline \multirow[t]{2}{*}{ In BITs 2} & .009 & .009 & .004 & -.001 \\
\hline & $(.04)$ & $(.04)$ & (.03) & $(.03)$ \\
\hline \multirow[t]{2}{*}{ pc GDP 1} & .092 & .092 & .028 & .086 \\
\hline & (.08) & $(.08)$ & $(.07)$ & (.08) \\
\hline \multirow[t]{2}{*}{ pc GDP 2} & $.136^{\star *}$ & $.136^{\star \star}$ & .071 & .108 \\
\hline & $(.05)$ & $(.05)$ & (.06) & (.06) \\
\hline \multirow[t]{2}{*}{ Democracy 1} & $.217^{\star \star \star}$ & $.217^{\star \star \star}$ & $.192^{\star \star}$ & $.219^{\star \star \star}$ \\
\hline & (.04) & $(.04)$ & $(.04)$ & (.04) \\
\hline \multirow[t]{2}{*}{ Democracy 2} & .067 & .067 & .048 & .069 \\
\hline & (.04) & (.04) & (.03) & $(.04)$ \\
\hline \multirow[t]{2}{*}{ Trade } & $.354^{\star \star *}$ & $.354^{\star \star \star}$ & $.321^{\star \star \star}$ & $.355^{\star \star \star}$ \\
\hline & (.02) & $(.02)$ & $(.02)$ & $(.02)$ \\
\hline \multirow[t]{2}{*}{ In Growth 1} & $.037^{\star}$ & $.037^{\star}$ & $.027^{\star}$ & $.036^{\star \star}$ \\
\hline & $(.01)$ & $(.01)$ & $(.01)$ & $(.01)$ \\
\hline \multirow[t]{2}{*}{ In Growth 2} & $-.045^{\star \star}$ & $-.045^{\star \star}$ & $-.039^{\star}$ & $-.042^{\star}$ \\
\hline & $(.01)$ & $(.01)$ & $(.01)$ & $(.01)$ \\
\hline \multirow[t]{2}{*}{ Constant } & $-5.123^{\star}$ & $-5.112^{*}$ & -1.755 & -4.315 \\
\hline & $(2.67)$ & $(2.66)$ & $(2.00)$ & $(2.66)$ \\
\hline $\mathrm{N}$ & 130235 & 130235 & 76116 & 122071 \\
\hline Year \& Dyad FE & Y & Y & Y & Y \\
\hline
\end{tabular}


Table 5. Missing values replaced with 0 .

\begin{tabular}{|c|c|c|c|c|}
\hline & Model 5 & Model 6 & Model 7 & Model 8 \\
\hline \multirow[t]{2}{*}{ BIT } & $-.279^{\star \star \star}$ & & $-.219^{\star \star \star}$ & $-.316^{\star \star \star}$ \\
\hline & $(.07)$ & & (.05) & $(.07)$ \\
\hline \multirow[t]{2}{*}{ BIT $\times$ Disjunctive Investors } & $.101^{\star \star \star}$ & & $.079^{\star \star \star}$ & $.115^{\star \star \star}$ \\
\hline & $(.01)$ & & $(.01)$ & $(.01)$ \\
\hline \multirow[t]{2}{*}{ Unrestricted BIT } & & $-.286^{\star \star \star}$ & & \\
\hline & & $(.07)$ & & \\
\hline \multirow[t]{2}{*}{ Unrestricted BIT $\times$ Disjunctive Investors } & & $.105^{\star \star \star}$ & & \\
\hline & & $(.01)$ & & \\
\hline \multirow[t]{2}{*}{ Restricted BIT } & & -.125 & & \\
\hline & & (.09) & & \\
\hline \multirow[t]{2}{*}{ Restricted BIT × Disjunctive Investors } & & .044 & & \\
\hline & & (.03) & & \\
\hline \multirow[t]{2}{*}{ Disjunctive Investors } & -.001 & -.001 & $-.004^{\star}$ & -.002 \\
\hline & $(.00)$ & $(.00)$ & $(.00)$ & $(.00)$ \\
\hline \multirow[t]{2}{*}{$\ln$ BITs 1} & .020 & .020 & -.008 & .027 \\
\hline & (.03) & (.03) & $(.01)$ & $(.02)$ \\
\hline \multirow[t]{2}{*}{ In BITs 2} & $.034^{\star \star}$ & $.034^{\star \star}$ & .011 & $.025^{\star}$ \\
\hline & $(.01)$ & $(.01)$ & $(.01)$ & $(.01)$ \\
\hline \multirow[t]{2}{*}{ pc GDP 1} & -.059 & -.059 & $-.039^{\star \star \star}$ & -.054 \\
\hline & $(.06)$ & $(.06)$ & $(.01)$ & $(.06)$ \\
\hline \multirow[t]{2}{*}{ pc GDP 2} & .027 & .028 & $.044^{\star \star}$ & .023 \\
\hline & $(.02)$ & $(.02)$ & $(.02)$ & $(.02)$ \\
\hline \multirow[t]{2}{*}{ Democracy 1} & $-.037^{\star \star \star}$ & $-.037^{\star \star \star}$ & $-.024^{\star \star \star}$ & $-.032^{\star \star \star}$ \\
\hline & $(.01)$ & $(.01)$ & $(.01)$ & $(.01)$ \\
\hline \multirow[t]{2}{*}{ Democracy 2} & $.033^{\star \star}$ & $.033^{\star \star}$ & $.032^{\star \star \star}$ & $.036^{\star \star *}$ \\
\hline & $(.01)$ & $(.01)$ & $(.01)$ & $(.01)$ \\
\hline \multirow[t]{2}{*}{ Trade } & $.033^{\star \star \star}$ & $.033^{\star \star \star}$ & $.024^{\star \star \star}$ & $.032^{\star \star \star}$ \\
\hline & (.01) & (.01) & $(.00)$ & $(.01)$ \\
\hline \multirow[t]{2}{*}{ In Growth 1} & $.011^{\star \star \star}$ & $.011^{\star \star \star *}$ & .003 & $.011^{\star \star \star}$ \\
\hline & $(.00)$ & $(.00)$ & $(.00)$ & $(.00)$ \\
\hline \multirow[t]{2}{*}{ In Growth 2} & -.002 & -.002 & -.002 & .001 \\
\hline & $(.00)$ & $(.00)$ & $(.00)$ & $(.00)$ \\
\hline \multirow[t]{2}{*}{ Constant } & .745 & .744 & -.127 & .736 \\
\hline & $(1.97)$ & (1.96) & $(.47)$ & $(1.73)$ \\
\hline $\mathrm{N}$ & 130235 & 130235 & 76116 & 122071 \\
\hline Year \& Dyad FE & Y & Y & $\mathrm{Y}$ & Y \\
\hline
\end{tabular}




\section{References}

Allee, Todd, and Clint Peinhardt. 2014. "Evaluating Three Explanations for the Design of Bilateral Investment Treaties." World Politics 66 (1): 47-87.

Antaloczy, K., and M. Sass. 2015. "Through a Glass Darkly: The Content of Statistical Data on Foreign Direct Investment." Studies in International Economics 1 (1): 34-61.

Arel-Bundock, Vincent. 2017. "The Unintended Consequences of Bilateralism: Treaty Shopping and International Tax Policy." International Organization 71 (2): 349-71.

Baldwin, Richard E. 2006. "Multilateralising Regionalism: Spaghetti Bowls as Building Blocs on the Path to Global Free Trade." World Economy 29 (11): 1451-1518.

Barry, Colin M., and Katja B. Kleinberg. 2015. "Profiting from Sanctions: Economic Coercion and US Foreign Direct Investment in Third-Party States.” International Organization 69 (4): 881-912.

Bubb, Ryan J., and Susan Rose-Ackerman. 2007. "BITs and Bargains: Strategic Aspects of Bilateral and Multilateral Regulation of Foreign Investment." International Review of Law and Economics 27 (3): 291-311.

Burt, Ronald. 1995. Structural Holes: The Social Structure of Competition. Cambridge, MA: Harvard University Press.

Carter, David B., and Curtis S. Signorino. 2010. "Back to the Future: Modeling Time Dependence in Binary Data." Political Analysis 18 (3): 271-92.

Cho, Seok-ju, Yong Kyun Kim, and Cheol-Sung Lee. 2016. “Credibility, Preferences, and Bilateral Investment Treaties." The Review of International Organizations 11 (1): 25-58.

Driscoll, John C., and Aart C. Kraay. 1998. "Consistent Covariance Matrix Estimation with Spatially Dependent Panel Data.” The Review of Economics and Statistics 80 (4): 549-60.

Elkins, Zachary, Andrew T. Guzman, and Beth A. Simmons. 2006. "Competing for Capital: The Diffusion of Bilateral Investment Treaties, 1960-2000.” International Organization 60 (4): 811-46.

Guzman, Andrew T. 1998. "Why LDCs Sign Treaties That Hurt Them: Explaining the Popularity of Bilateral Investment Treaties." Virginia Journal of International Law 38: 639-88.

Haberly, Daniel, and Dariusz Wójcik. 2015. "Regional Blocks and Imperial Legacies: Mapping the Global Offshore FDI Network.” Economic Geography 91 (3): 251-80.

Hallward-Driemeier, Mary. 2009. Do Bilateral Investment Treaties Attract FDI? Only a Bit ... and They Could Bite. In The Effect of Treaties on Foreign Direct Investment: Bilateral Investment Treaties, Double Taxation Treaties, and Investment Flows, edited by Karl Sauvant and Lisa Sachs. New York: Oxford University Press.

Jandhyala, Srividya, Witold J. Henisz, and Edward D. Mansfield. 2011. “Three Waves of BITs: The Global Diffusion of Foreign Investment Policy." Journal of Conflict Resolution 55 (6): 1047-73.

Jensen, Nathan M. 2003. "Democratic Governance and Multinational Corporations: Political Regimes and Inflows of Foreign Direct Investment.” International Organization 57 (3): 587-616.

Jensen, Nathan Michael. 2006. Nation-States and the Multinational Corporation: A Political Economy of Foreign Direct Investment. Princeton, NJ: Princeton University Press.

Jensen, Nathan. 2008. "Political Risk, Democratic Institutions, and Foreign Direct Investment." The Journal of Politics 70 (4): 1040-52.

Johns, Leslie, and Rachel L. Wellhausen. 2016. "Under One Roof: Supply Chains and the Protection of Foreign Investment." American Political Science Review 110 (1): 31-51.

Kahale, George. 2011. "The New Dutch Sandwich: The Issue of Treaty Abuse." Columbia FDI Perspectives 48: 1-3.

Kalotay, Kálmán. 2012a. "Does It Matter Who Invests in Your Country?" Columbia FDI Perspectives 66: 15.

Kalotay, Kálmán. 2012b. “Indirect FDI.” The Journal of World Investment \& Trade 13 (4): 542-55.

Kerner, Andrew. 2014. "What We Talk About When We Talk About Foreign Direct Investment." International Studies Quarterly 58 (4): 804-15.

Kerner, Andrew, and Jane Lawrence. 2014. "What's the Risk? Bilateral Investment Treaties, Political Risk and Fixed Capital Accumulation." British Journal of Political Science 44 (1): 107-21.

Lektzian, David, and Glen Biglaiser. 2013. "Investment, Opportunity, and Risk: Do US Sanctions Deter or Encourage Global Investment?” International Studies Quarterly 57 (1): 65-78.

Lewellen, Katharina, and Leslie A. Robinson. 2013. Internal Ownership Structures of U.S. Multinational Firms. SSRN Scholarly Paper ID 2273553 Social Science Research Network Rochester, NY.

Li, Quan, and Adam Resnick. 2003. "Reversal of Fortunes: Democratic Institutions and Foreign Direct Investment Inflows to Developing Countries.” International Organization 57 (1): 175-211.

Li, Quan, and Tatiana Vashchilko. 2010. "Dyadic Military Conflict, Security Alliances, and Bilateral FDI Flows." Journal of International Business Studies 41 (5): 765-82.

Lipsey, Robert E. 2007. "Defining and Measuring the Location of FDI Output.” Technical Report 12966 National Bureau of Economic Research Working Paper Series.

Matyas, Laszlo. 1997. "Proper Econometric Specification of the Gravity Model.” World Economy 20 (3): 363-68.

Muchlinski, Peter. 2009. “The Framework of Investment Protection: The Content of BITs.” In The Effect of Treaties on Foreign Direct Investment: Bilateral Investment Treaties, Double Taxation Treaties, and Investment Flows, edited by Karl Sauvant and Lisa Sachs. New York: Oxford University Press.

Neumayer, Eric, and Thomas Plümper. 2010. “Spatial Effects in Dyadic Data.” International Organization 64 (1): $145-66$. 
Neumayer, Eric, and Laura Spess. 2005. "Do Bilateral Investment Treaties Increase Foreign Direct Investment to Developing Countries?” World Development 33 (10): 1567-85.

Poulsen, Lauge Skovgaard. 2010. “The Significance of South-South BITs For the International Investment Regime: A Quantitative Analysis." Northwestern Journal of International Law and Business 30 (1): 101-30.

Poulsen, Lauge Skovgaard. 2013. "Bounded Rationality and the Diffusion of Modern Investment Treaties." International Studies Quarterly 58 (1): 1-14.

Seabrooke, Leonard, and Duncan Wigan. 2017. “The Governance of Global Wealth Chains.” Review of International Political Economy 24 (1): 1-29.

Sikka, Prem. 2003. “The Role of Offshore Financial Centres in Globalization.” Accounting Forum 27 (4): 365-99.

Simmons, Beth A. 2014. "Bargaining over BITs, Arbitrating Awards: The Regime for Protection and Promotion of International Investment.” World Politics 66 (1): 12-46.

Thompson, Alexander, Tomer Broude, and Yoram Z. Haftel. 2019. "Once Bitten, Twice Shy? Investment Disputes, State Sovereignty, and Change in Treaty Design.” International Organization 73 (4): 859-80.

Tobin, Jennifer L., and Marc L. Busch. 2010. "A BIT Is Better Than a Lot: Bilateral Investment Treaties and Preferential Trade Agreements.” World Politics 62 (1): 1-42.

Tobin, Jennifer L., and Susan Rose-Ackerman. 2011. "When BITs Have Some Bite: The Political-Economic Environment for Bilateral Investment Treaties." The Review of International Organizations 6 (1): 1-32.

UNCTAD. 1990. "Italy-Argentina Bilateral Investment Treaty."

Vandevelde, Kenneth J. 2005. “A Brief History of International Investment Agreements.” U.C. Davis Journal of International Law \& Policy 12: 157.

Vernon, Raymond. 1971. Sovereignty at Bay: The Multinational Spread of U.S. Enterprises. New York: Basic Books.

Cite this article: Tomashevskiy A (2022). Networked capital: indirect investment and BIT formation. Business and Politics 24, 36-56. https://doi.org/10.1017/bap.2021.11 